\title{
WIRELESS CONTROL PROCESS TECHNICAL EXPLOITATION FACILITY
}

\section{BEZPRZEWODOWE STEROWANIE PROCESEM EKSPLOATACJI OBIEKTU TECHNICZNEGO}

\author{
Jacek Paś
}

Wojskowa Akademia Techniczna

\begin{abstract}
In the article presents issues related to the control for which wireless is utilized in object technology. During the tests performed the technical parameters were determined the quality of control the object of the mobile cellular telephone system. It also analyzes the impact of the delay time of signal transmission control on the technical parameters of the object.
\end{abstract}

Keywords: transmission, control, technical object

Streszczenie: $W$ artykule przedstawiono zagadnienia zwiazane ze sterowaniem bezprzewodowym, które wykorzystywane jest $w$ obiekcie technicznym. Podczas wykonanych badań technicznych określono parametry jakości sterowania obiektu $z$ mobilnego systemu telefonii komórkowej. Przeprowadzono również analize wptywu czasu opóźnienia transmisji sygnatu sterujacego na parametry techniczne obiektu.

Stowa kluczowe: transmisja, sterowanie, obiekt techniczny 
Wireless control process technical exploitation facility

Bezprzewodowe sterowanie procesem eksploatacji obiektu technicznego

\section{Introduction}

Wireless transmission technology enabled m. In. remote control of complex processes operating technical objects. Control of complex technical object should allow the remote to change the operational parameters specified previously limited the terms of the security interval. Temperature control central heating boiler is a constant change of extortion input. Changing temperatures should be continuously monitored regardless of changes in operating conditions or internal affairs. The user should have the feedback information in the event of irregularities in the use of a technical object - CO furnace with automatic control weather. In the basic version of the remote control we should have information about the set temperature in any room, hearth $\mathrm{CO}$. Expansion of the technical possibilities of the control system and process management operation, energy efficiency energy consumption necessitated a new mode of operation of the boiler CO. Control depends on the conditions of the outside temperature. You can automatically use previously developed procedures for controlling the temperature inside the building. The object control should also enable temperature control running water. Communication between the user and the driver of a technical facility will use allowable standard mobile networks in the country, ie. GSM. Control will take place with the help of SMS. At the same time specialized electronics boiler allow the use of its own operating programs. The use of autonomous control programs is the optimal use of the boiler reduce the consumption of electricity in the factor of fuel which is consumed during the operation.

\section{The consumption of electricity during operation of the facility}

Research related to electrical energy consumption by the device are made in the actual operating conditions for maximum permissible load. During the study provided the following fixed parameters of the internal extortion: fuel, outside temperature and internal chimney section, the initial temperature of the space heating and hearth and humidity. The fuel (heating medium) was fed continuously and in such a quantity that was required at the time. The user asked to force the input in the form of changes in temperature, and the furnace $\mathrm{CO}$ using electrical appliances perform all operations automatically. To stabilize the temperature set point is used to control ventilator or variable speed circulation pumps. The solution that effectively improves the control is to use the PID controller. In the case of less advanced drivers - after reaching the set temperature object off the airflow. If there is a temperature drop below the programmed room controller switches again blowing fan. This results in significant changes in temperature and firing Fading boiler - Fig. 1. In the driver, you can set the strength of the fan blower - ie. The 
burning rate. The study power consumption of individual devices implementing the boiler was associated with an indication of their maximum values in the process of exploitation. Determination of the power subscribed in the individual cycles of the boiler will be used to determine the type actuators (relays, contactors and current protection), and to build a control interface using wireless technology.
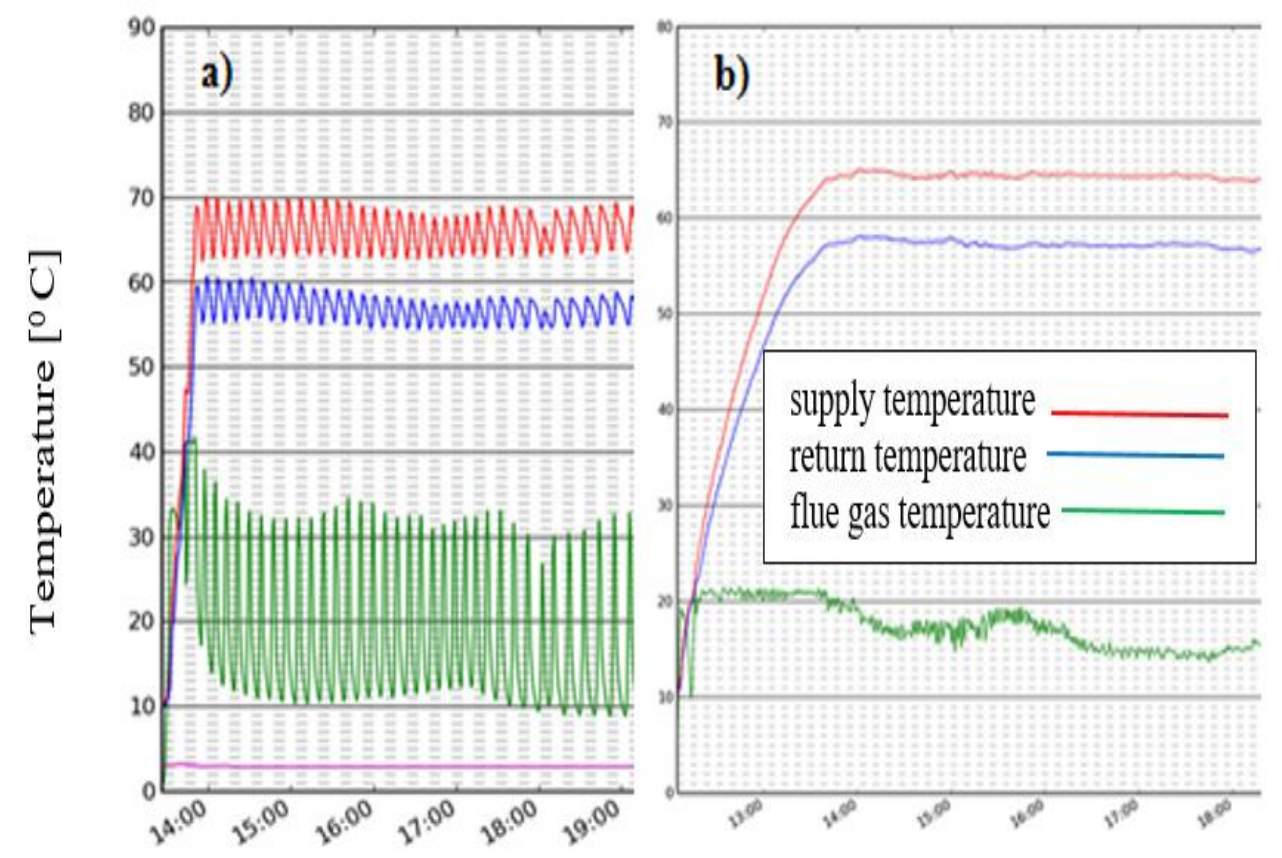

Fig. 1. Automatic adjustment of temperature set point a) without the use of a PID controller, $b$ ) using PID

For one operation cycle research facility three hours, where they observed two phases of work, ie. Lighting of the flame inside the furnace and allow it to continue. Studies have been made for a device with a specific power of the installed PID controller and without - Fig. 2a, b. Fig. 2 c shows the total value of power consumption $\mathrm{w} /$ accessories in a technical object.

A characteristic feature of the process of operating a pulsed power consumption associated with starting the engine fuel feeder - Fig. 3. Fuel energy is served by a certain time, later followed by fixed interval that does not depend on the parameters of the heating system. 
Wireless control process technical exploitation facility
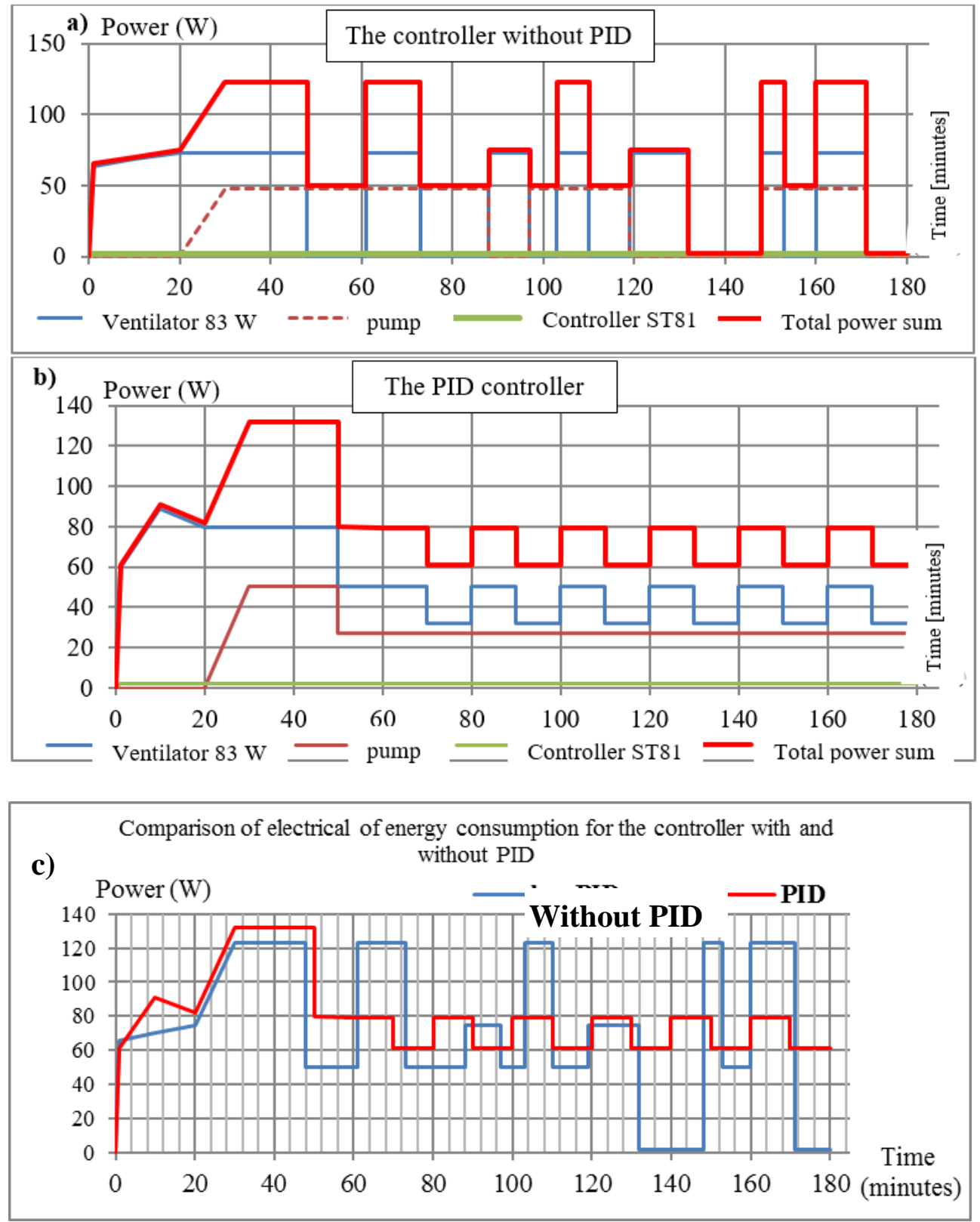

Fig. 2. Power consumption $P[W]$ by each unit during a control operation a) without PID controller, $b$ ) using a PID controller, $c$ ) a summary comparison of the electrical power consumption of the device and without driver 


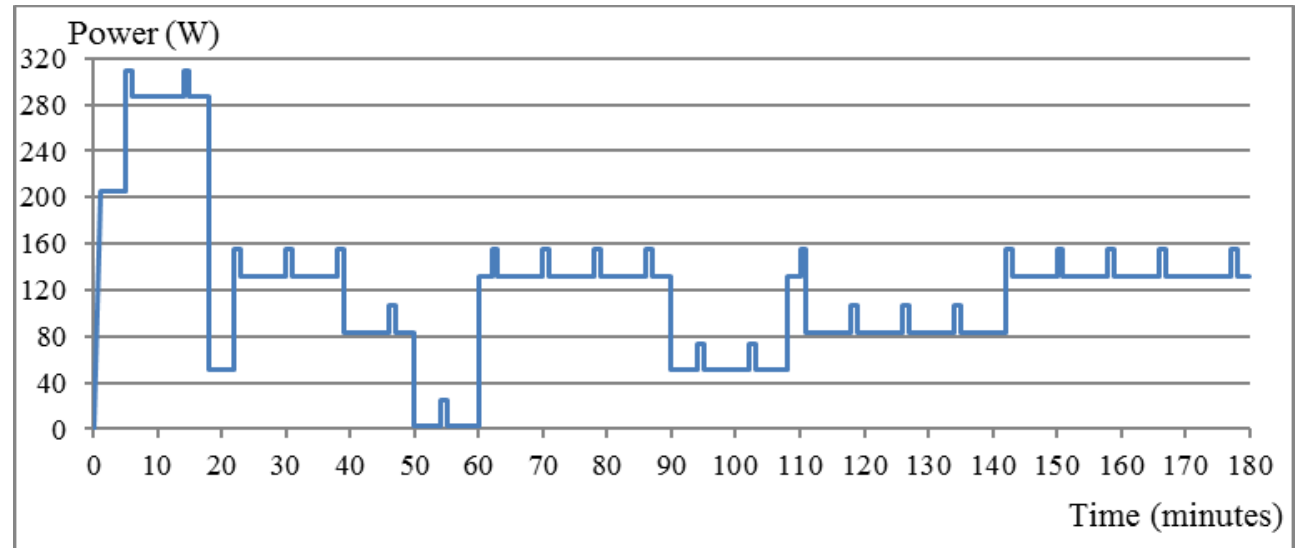

Fig. 3. Resultant electric power consumption for of the boiler automatic

\section{Model of process control operation of the facility}

Fig. 4 shows a model of the user control in the feedback loop. Boiler control is carried out thanks to information that can be obtained independently without participation of electronic devices using only the sensor readings.

the outside

temperature

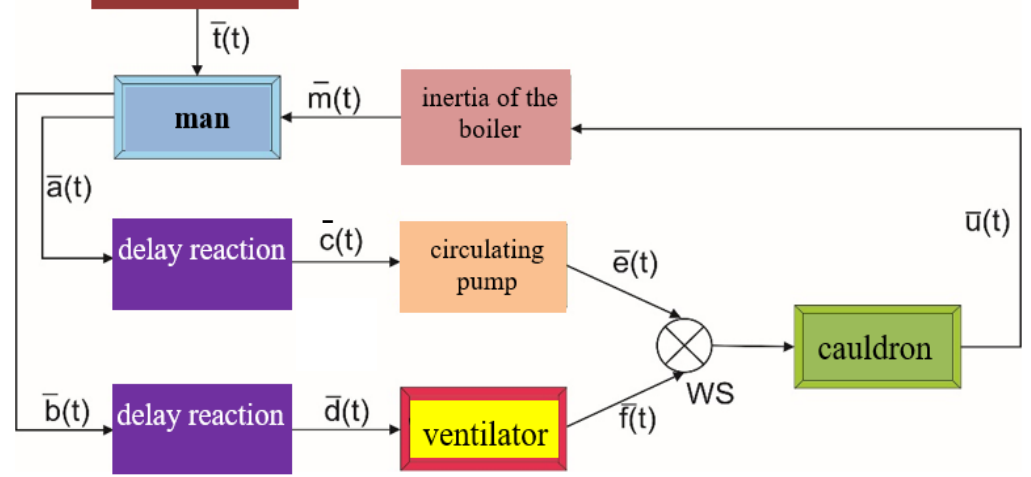

Fig. 4. Model control operation - the user in the feedback loop

The control system Fig. 4 - there are lag effects temperature reading - a man reaction (pump or fan). Measuring the water temperature on the output of the boiler and the outside temperature, taking into account delays can lead to a dangerous situation for the user, ie. Overtemperature at the output of the boiler. It leads to explode, if there is sufficient mechanical protection. With the development of production technology and control introduced electronic devices that allow precise control - eg. A reduction in delay times. Thanks to this increased possibility of controlling complex technical object. 


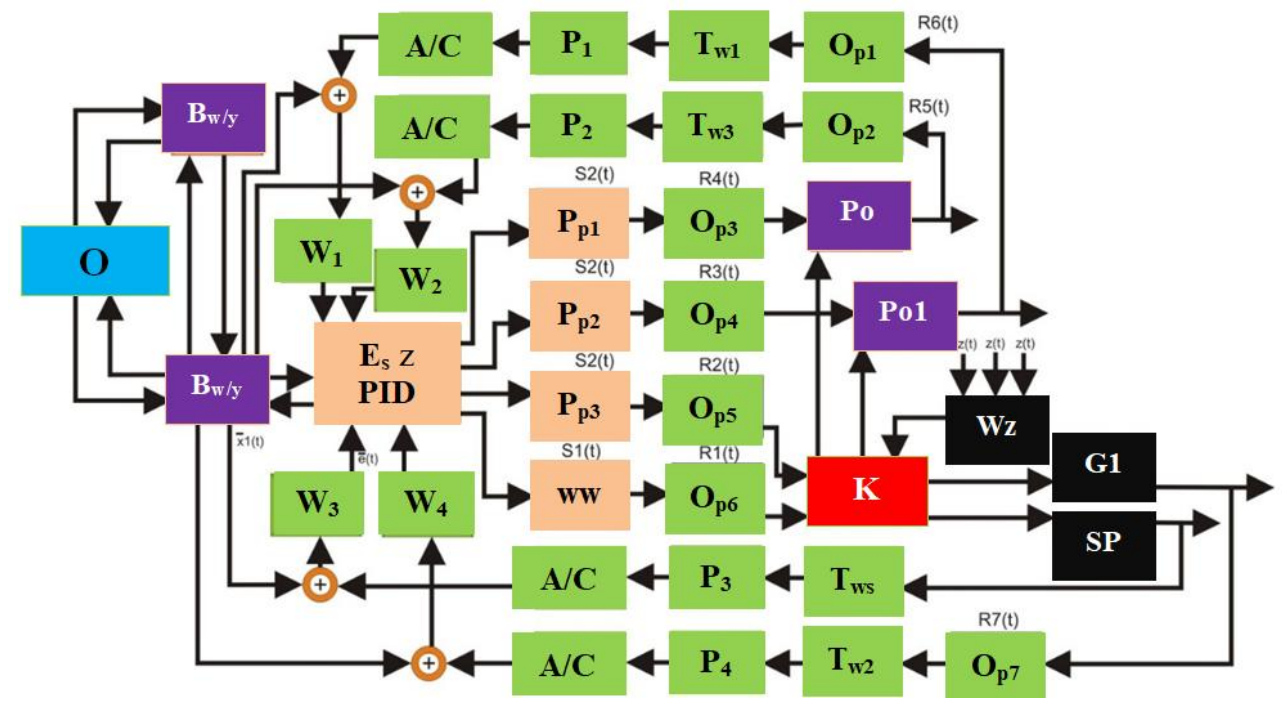

Fig. 5. Schematic model of the system with automatic fuel feeder

where: $O_{p 1} \div O_{p 7}$ - the delay associated with the implementation of each process control boiler CO, A/C - analog-to-digital converter, $W_{1} \div W_{4}$ - analog signal amplifiers, $P_{1} \div P_{4}-$ converters (analog signal conditioning circuits), $T_{w 1} \div T_{w 3}$ - water temperature sensor, $T_{w s}$ - flue gas temperature sensor, $K$ - boiler, $O$ - operator, $P_{p 1} \div P_{p 3}$ - water pump, ww-fan, Es - control element with PID regulator, $B_{w / y}$ - input and output signal processing block, Po - heating proces, Pol - water heating proces, Wz-external atmospheric conditions, G1-process of water heating in the installation $C O, S P$ - burning and smoking process.

The principle of operation of the PID controller is that the controller operates in a feedback loop. The controller calculates the control error as the difference between the measured value of the process variable and desired set point. Adjusts the size so as to reduce the error. The PID controller consists of three main units: proportional, integral and derivative denoted by $\mathrm{P}, \mathrm{I}$ and $\mathrm{D}$. The proportional PID strengthens the deviation and ensure its gradual decrease. The increase $K_{p}$ will decrease the supply of stability, expanding the frequency range and ratio and drop of. Step change in control signal is the value of displacement. It is proportional to the change of the output signal, and the error condition adjustment is not completely liquidated (ie. A static control deviation). The integral component of the PID controller causes the correction in the low frequencies, making the effect and drop of.

Integral to the higher frequency decreases significantly strengthen limits the working band as well as introduces a phase shift, equal to $-\pi / 2$, leading to a deterioration of stability. Integral reacts slowly to changes in the signal controlled. Size adjustable oscillating around its average value is reduced to zero offset adjustment. 
The combined action of taking advantage of integration eliminates the disadvantages, since it introduces a phase shift, and does not limit the bandwidth. The derivative is used in order to accelerate waveforms occurring in the control system. The output of the differentiating element is proportional to the rate of change of the input signal, not depending on its amplitude. In connection with the means and integrating the proportional effects of differentiating element is introduced to the signal output from the control component dependent on the rate of change of the control deviation. Overall, the combination of activities provides an increase in supply stability, strengthening and extension of the frequency range. In controllers with PID fan power is calculated by measuring the temperature of the boiler and flue gas. Fan operation is carried out continuously over time, the fan power is a function of the temperature of the boiler, flue gas temperature and the difference between these parameters references. To maintain a stable temperature without unnecessary overshoot and oscillations are the advantages of PID. Fuel savings with the use of PID can range from a few to several percent.

\section{Experimental research facility control systems}

In-service testing of the control system with the following parameters:

- delay currently top - the time difference and give the message is received at the output of the controller boiler - Fig. 6;

- response times object to the message transmitted by the temperature controller installed in the room and received via GSM module - Fig. 7;

- specify the time correction controller for temperature jump at the input of the boiler - Fig. 8;

- the impact of the network operator for the delay time top control boiler CO - Fig. 9;

- the impact of the location of the mobile terminal for the duration of the delay sent the message - tab. 1;

- the impact of time to send control commands on the working day on top - Fig. 10;

- averages of time transferring control commands within the control object (control module - Electrical and electronic equipment) - Fig. 11.

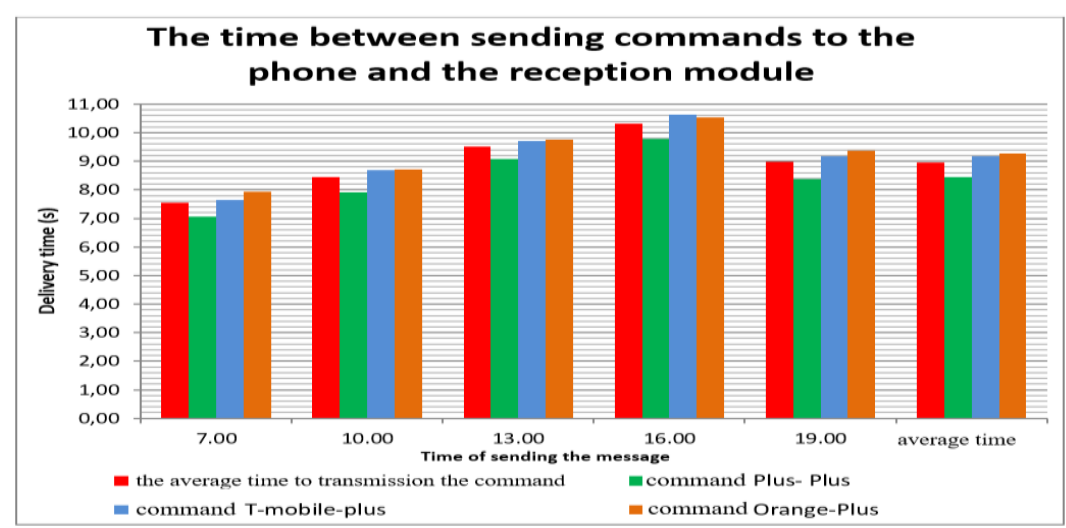

Fig. 6. The delay time between sending commands to the mobile terminal and the reception by the control module furnace $\mathrm{CO}$ 
Wireless control process technical exploitation facility

Bezprzewodowe sterowanie procesem eksploatacji obiektu technicznego

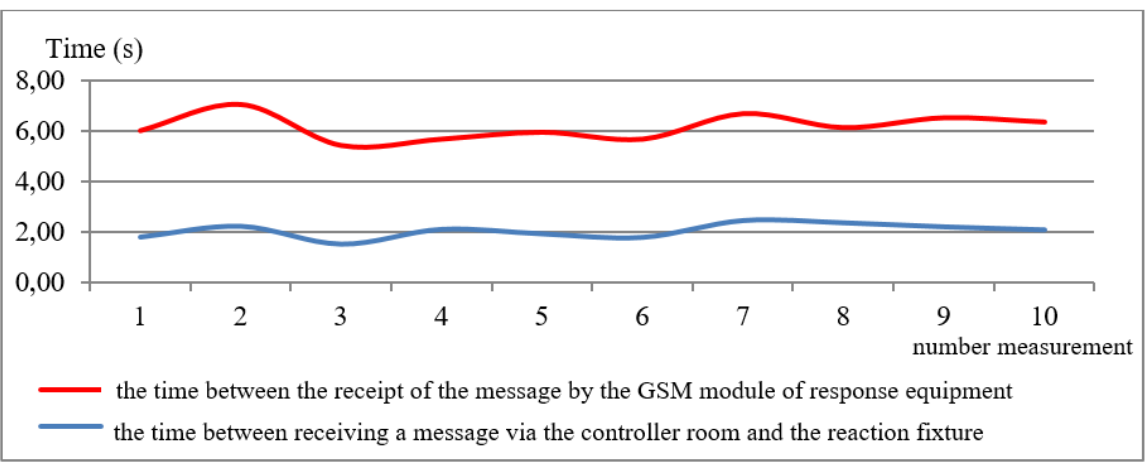

Fig. 7. Comparison of response times of receipt of the message by the temperature controller installed in the room with the message received by GSM module
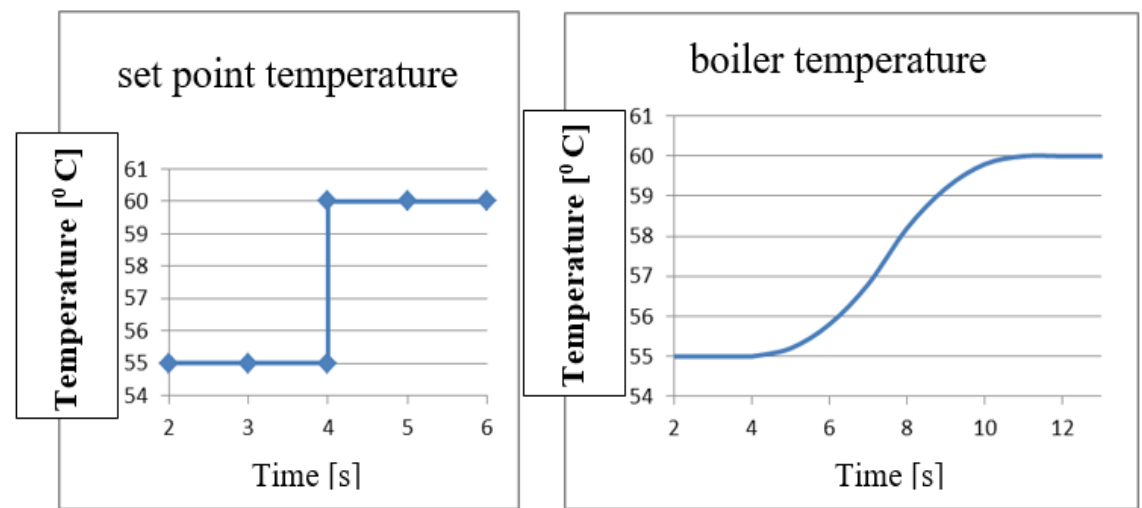

Fig. 8. The course set temperature and answers - starting temperature in the system for forcing the ankle to the controller input about $5^{\circ} \mathrm{C}$

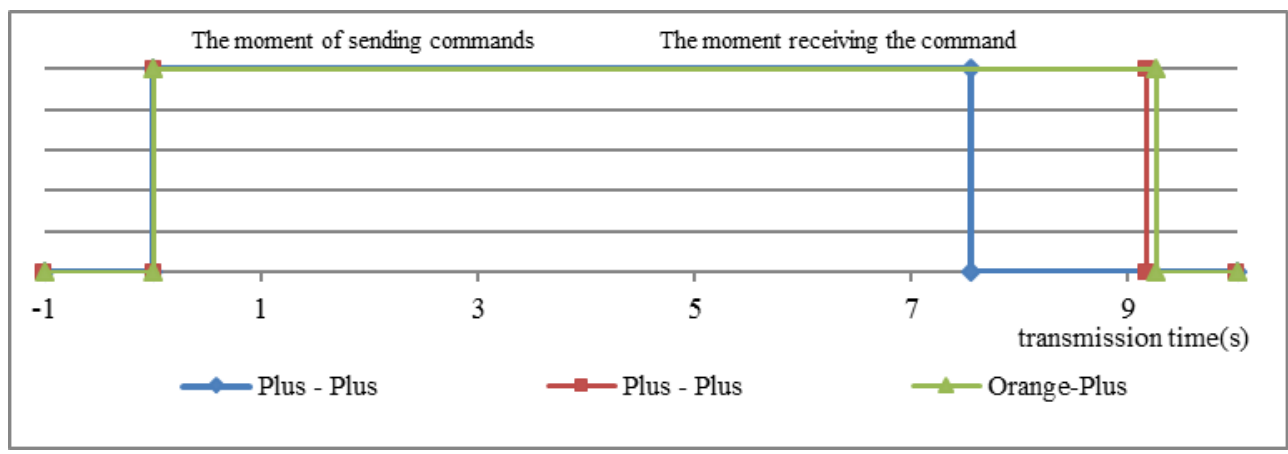

Fig. 9. The mean time transmission of commands depending on the mobile operator 
Table 1. The mean time communication and mobile phone GSM controller technical object

\begin{tabular}{|c|c|c|c|c|c|c|}
\hline \multicolumn{7}{|c|}{ Card test driver with GSM module - averaged } \\
\hline Date & 09.06 & Unit o & f measur & ement & $\sec$ & ind \\
\hline \multicolumn{3}{|c|}{ Place the boiler installation } & \multicolumn{4}{|c|}{$\mathrm{Xxxx}$} \\
\hline \multicolumn{3}{|c|}{ Place of dispatch of commands } & \multicolumn{4}{|c|}{ Yyyy } \\
\hline & 7.00 & 10.00 & 13.00 & 16.00 & 19.00 & Average \\
\hline & average & average & average & average & average & \\
\hline $\begin{array}{l}\text { The time between sending a } \\
\text { command and the reception of }\end{array}$ & 7,81 & 8,59 & 10,05 & 11,30 & 9,66 & 9,48 \\
\hline Plus- Plus & $\overline{7,42}$ & 8,11 & 9,58 & 10,69 & 9,09 & 8,98 \\
\hline T-mobile-plus & 7,95 & 8,81 & 10,26 & 11,58 & 9,92 & 9,70 \\
\hline Orange-Plus & 8,05 & 8,87 & 10,33 & 11,63 & 9,97 & 9,77 \\
\hline $\begin{array}{l}\text { Time of delivery from a delivery } \\
\text { report for sending a command }\end{array}$ & 15,16 & 16,68 & 19,59 & 21,96 & 18,72 & 18,42 \\
\hline Plus- Plus & 14,84 & 16,30 & 19,11 & 21,43 & 18,29 & 17,99 \\
\hline Plus-T-mobile & 15,12 & 16,64 & 19,65 & 21,95 & 18,65 & 18,40 \\
\hline Plus - Orange & 15,51 & 17,10 & 20,01 & 22,51 & 19,22 & 18,87 \\
\hline $\begin{array}{l}\text { Time of sending commands to the } \\
\text { controller replies }\end{array}$ & 21,01 & 22,75 & 25,65 & 28,27 & 24,92 & 24,52 \\
\hline Plus- Plus & 20,24 & 21,78 & 24,70 & 27,15 & 23,87 & 23,55 \\
\hline Plus-T-mobile & 21,29 & 23,00 & 25,90 & 28,63 & 25,20 & 24,80 \\
\hline Plus-Orange & 21,51 & 23,47 & 26,37 & 29,05 & 25,71 & 25,22 \\
\hline
\end{tabular}

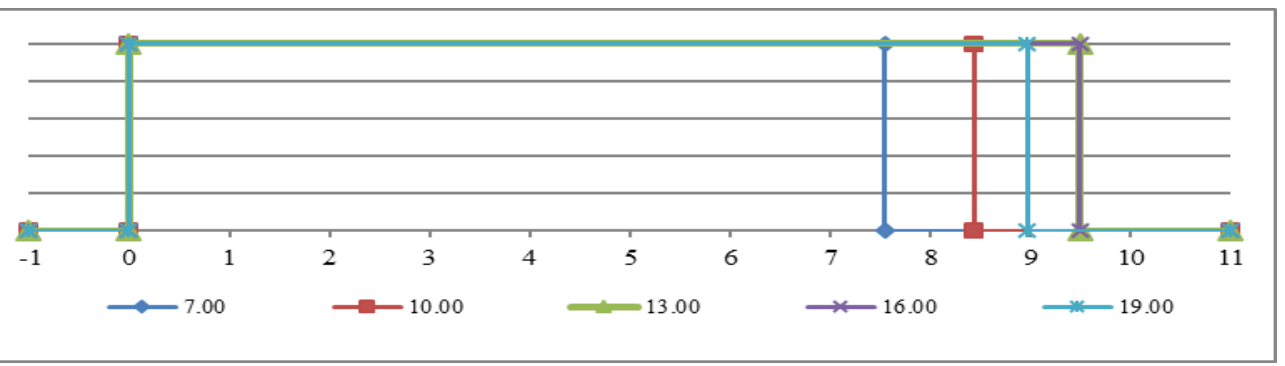

Fig. 10. Average values of the time of transmission control message to the object as a function of time for sending a message (eg. 13.00 - the time of sending the command)

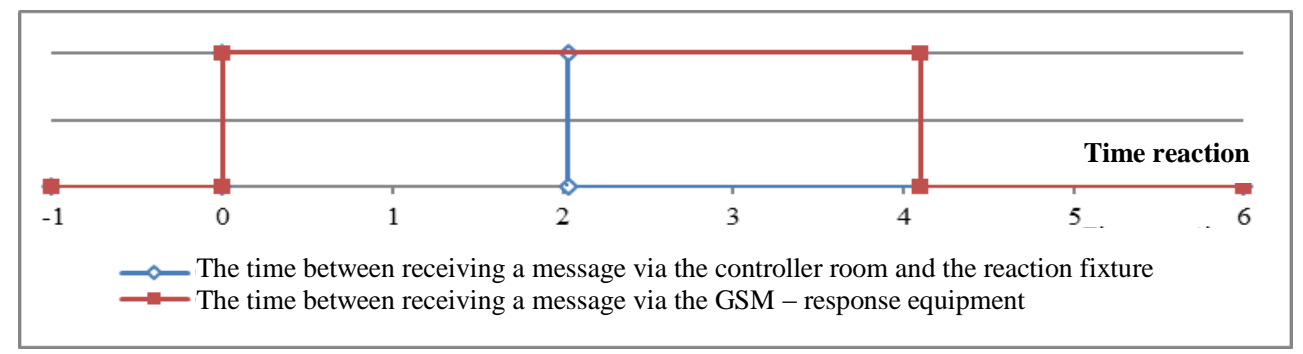

Fig. 11. Average values of transmission time control commands within the control object (control module electrical equipment and electronic object) 
Wireless control process technical exploitation facility

Bezprzewodowe sterowanie procesem eksploatacji obiektu technicznego

\section{Conclusions}

The paper presents the results of research the possibilities of using wireless control for a technical object using a mobile phone terminal. Technical solutions and used equipment, electric and electronic object allow the use of such solutions.

As a result of technical research the delay times transmitted and received messages in the operating system you can determine the impact of the following parameters for quality control: the installation location of the object (room, terrain, buildings, distance from the transceiver); hour establish communications (in the morning time messaging is much shorter than 7,5 seconds in the afternoon 9,5 s); times transmit control commands depend on the mobile network operator (Network Plus - 7,4 s, Orange 9,3 s); kind of communication / control internal or external (reaction time to changes in temperature depends on the type of driver is used - peaceful or GSM).

\section{Literature}

[1] Będkowski L., Dąbrowski T.: Podstawy eksploatacji, cz. II Podstawy niezawodności eksploatacyjnej. Warszawa: Wojskowa Akademia Techniczna, 2006.

[2] Staniszewski R.: Sterowanie procesem eksploatacji, WNT Warszawa 1990.

[3] Węgrzyn S.: Podstawy automatyki, PWN, Warszawa 1980.

[4] J. Dyduch, J. Paś, A. Rosiński, The basic of the exploitation of transport electronic systems. Radom, Poland: Publishing House of Radom University of Technology, 2011.

[5] Laskowski, D., Łubkowski, P., Pawlak, E., Stańczyk, P.: Anthropotechnical systems reliability. In: the monograph „Safety and Reliability: Methodology and Applications - Proceedings of the European Safety and Reliability Conference ESREL 2014”, editors: Nowakowski T., Młyńczak M., JodejkoPietruczuk A. \&Werbińska-Wojciechowska S. CRC Press/Balkema, London, 2015, pp. 399-407.

[6] J. Paś, Operation of electronic transportation systems. Radom, Poland: Publishing House University of Technology and Humanities, 2015.

[7] A. Rosiński, Modelling the maintenance process of transport telematics systems. Warsaw, Poland: Publishing House Warsaw University of Technology, 2015.

[8] Rosiński A.: Reliability-exploitation analysis of power supply in transport telematics system. In: „Safety and Reliability: Methodology and Applications - Proceedings of the European Safety and Reliability Conference ESREL2

[9] Siergiejczyk M., Rosiński A., Paś J.: Analysis of unintended electromagnetic fields generated by safety system control panels. Diagnostyka 2016, vol. 17, no. 3, pp. 35-40.

[10] Paś J.: Shielding of the electromagnetic field in the range of small frequencies as the factor for ensuring compatibility in electronic transportation systems. Archives of Transport System Telematics, pp. 36 - 41, Volume 9, Issue 3, September 2016

[11] Paś J., Choromański W.: Results of measurement and determination of threshold electric field component for transport security systems. Archives of Transport Systems Telematics, pp. 24 - 29, Volume 8, Issue 1, February 2015 
[12] T. Perzyński, A. Lewiński, Z. Łukasik, "Safety analysis of accidents call system especially related to in-land water transport based on new telematic solutions," in Communications in Computer and Information Science, Tools of Transport Telematics, no. 531, Berlin Heidelberg, Germany: SpringerVerlag, 2015, pp. 90-98.

[13] M. Stawowy, "Model for information quality determination of teleinformation systems of transport," in Proceedings of the European Safety and Reliability Conference ESREL 2014, Wroclaw, Poland, 2015, pp.1909-1914.

[14] M. Sumila, "Selected aspects of message transmission management in ITS systems," in Telematics in the transport environment, vol. 329, Berlin Heidelberg, Germany: Springer-Verlag, 2012, pp. 141-147.

[15] P. Lubkowski, D. Laskowski, "Selected issues of reliable identification of object in transport systems using video monitoring services," in Communication in Computer and Information Science, vol. 471, Berlin Heidelberg, Germany: Springer, 2015, pp. 59-68.

[16] S. Duer, K. Zajkowski, R. Duer, J. Paś, "Designing of an effective structure of system for the maintenance of a technical object with the using information from an artificial neural network," Neural Computing \& Applications, vol. 23, issue 3, pp. 913-925, 2012

[17] M. Siergiejczyk, J. Paś, A. Rosiński, "Issue of reliability-exploitation evaluation of electronic transport systems used in the railway environment with consideration of electromagnetic interference," IET Intelligent Transport Systems, vol. 10, issue 9, pp. 587-593, 2016. DOI: 10.1049/iet-its.2015.0183.

[18] M. Siergiejczyk, J. Paś, A. Rosiński, "Modeling of process of exploitation of transport telematics systems with regard to electromagnetic interferences," in Tools of transport telematics", vol. 531, Berlin Heidelberg, Germany: Springer, 2015. pp. 99-107.

[19] S. Dudoyer, V. Deniau, S. Ambellouis, M.Heddebaut, A. Mariscotti, "Classification of transient EM noises depending on their effect on the quality of GSM-R reception," IEEE Transactions on Electromagnetic Compatibility, vol. 55 , no. 5 , pp. $867-874,2013.32$

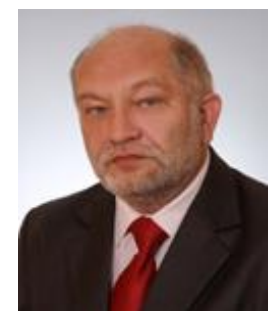

Jacek Paś Ph.D., D.Sc., Eng., professor of Military University of Technology - Division Electronic Systems Exploitations Manager, scientific interests (electromagnetic compatibility, analog circuits, reliability, low frequency noise, exploitation, diagnostics, projecting) are problems connected with comprehended wide of the safety both for stationary as well as for movable objects. He is the author of three books and more than 150 articles. His research interests include also environmental studies of electromagnetic the range at low frequencies at (electrosmog). 
Wireless control process technical exploitation facility

Bezprzewodowe sterowanie procesem eksploatacji obiektu technicznego

\section{BEZPRZEWODOWE STEROWANIE PROCESEM EKSPLOATACJI OBIEKTU TECHNICZNEGO}

\section{Wstęp}

Bezprzewodowa technologia transmisji danych umożliwiła $\mathrm{m}$. in. zdalne sterowanie złożonymi procesami eksploatacji obiektów technicznych. Sterowanie złożonym obiektem technicznym powinno umożliwiać zdalną zmianę parametrów eksploatacyjnych w zadanym, wcześniej ograniczonym warunkami bezpieczeństwa przedziale. Sterowanie temperaturą kotła CO to ciągła zmiana wymuszeń wejściowych. Zmiana temperatury powinny być w ciągły sposób kontrolowane niezależnie od zmian warunków eksploatacyjnych wewnętrznych lub wewnętrznych. Użytkownik powinien posiadać zwrotną informację w przypadku wystąpienia nieprawidłowości podczas użytkowania obiektu technicznego - pieca $\mathrm{CO}$ z automatycznym sterowaniem pogodowym. W podstawowej wersji sterowania zdalnego powinniśmy posiadać informację o zadanej temperaturze w wybranym pomieszczeniu i palenisku CO. Rozbudowa możliwości technicznych systemu sterowania i zarządzania procesem eksploatacji, energooszczędność zużycia energii wymusiły nowy tryb pracy kotła CO. Sterowanie uzależnione jest od warunków zewnętrznej temperatury. Istnieje możliwość automatycznego stosowania wcześniej opracowanych procedur sterowania temperaturą wewnątrz budynku. Obiekt sterowania powinien umożliwiać także sterowanie temperaturą wody bieżącej. Komunikacja między użytkownikiem a sterownikiem obiektu technicznego będzie wykorzystywała dopuszczalny standard sieci komórkowych w kraju tj. GSM. Sterowanie będzie się odbywało przy pomocy sms. Jednocześnie specjalizowane układy elektroniczne kotła CO umożliwiają wykorzystanie własnych programów eksploatacyjnych. Stosowanie autonomicznych programów sterowania to optymalne wykorzystanie kotła $\mathrm{CO}$ zmniejszenie poboru energii elektrycznej w tym czynnika opałowego który zużywany jest w czasie eksploatacji.

\section{Zużycie energii elektrycznej podczas eksploatacji obiektu}

Badania związane $\mathrm{z}$ poborem energii elektrycznej przez urządzenie zostały wykonane w rzeczywistych warunkach eksploatacyjnych dla dopuszczalnych maksymalnych obciążeń. Podczas badań zapewniono następujące stałe parametry wymuszeń wewnętrznych: paliwo, temperatura zewnętrzna i wewnętrzna, przekrój komina, początkowa temperatura pomieszczeń grzewczych i paleniska, wilgotność. Paliwo (czynnik grzewczy) był podawany w sposób ciągły i w takiej ilości, która była wymagana w danej chwili. 
Użytkownik zadawał wymuszenie wejściowe w postaci zmiany temperatury, a piec CO wykorzystując urządzenia elektryczne wykonywał wszystkie czynności automatycznie. Do stabilizacji zadanej temperatury wykorzystuje się sterowanie wentylatorem nadmuchowym lub regulację obrotów pomp obiegowych. Rozwiązaniem które skutecznie poprawia warunki sterowania jest wykorzystanie sterownika PID.

W przypadku stosowania mniej zaawansowanych sterowników - po osiągnięciu zadanej temperatury obiekt wyłącza nadmuch powietrza. Jeżeli wystąpi spadek temperatury poniżej zaprogramowanej $\mathrm{w}$ pomieszczeniu sterownik załącza ponownie wentylator nadmuchowy. Powoduje to znaczne zmiany temperatury rozpalania i przygaszanie kotła CO - rys. 1. W sterowniku istnieje możliwość ustawienia siły nadmuchu wentylatora - tj. szybkości spalania. Badanie poboru mocy przez poszczególne urządzenia wykonawcze kotła $\mathrm{CO}$ związane było $\mathrm{z}$ określeniem ich maksymalnych wartości $\mathrm{w}$ procesie eksploatacji. Określenie wartości mocy zapotrzebowanej $\mathrm{w}$ poszczególnych cyklach pracy kotła będzie wykorzystane do określenia typu urządzeń wykonawczych (przekaźniki, styczniki i zabezpieczenia prądowe) oraz do budowy interfejsu sterującego wykorzystującego technikę bezprzewodową.
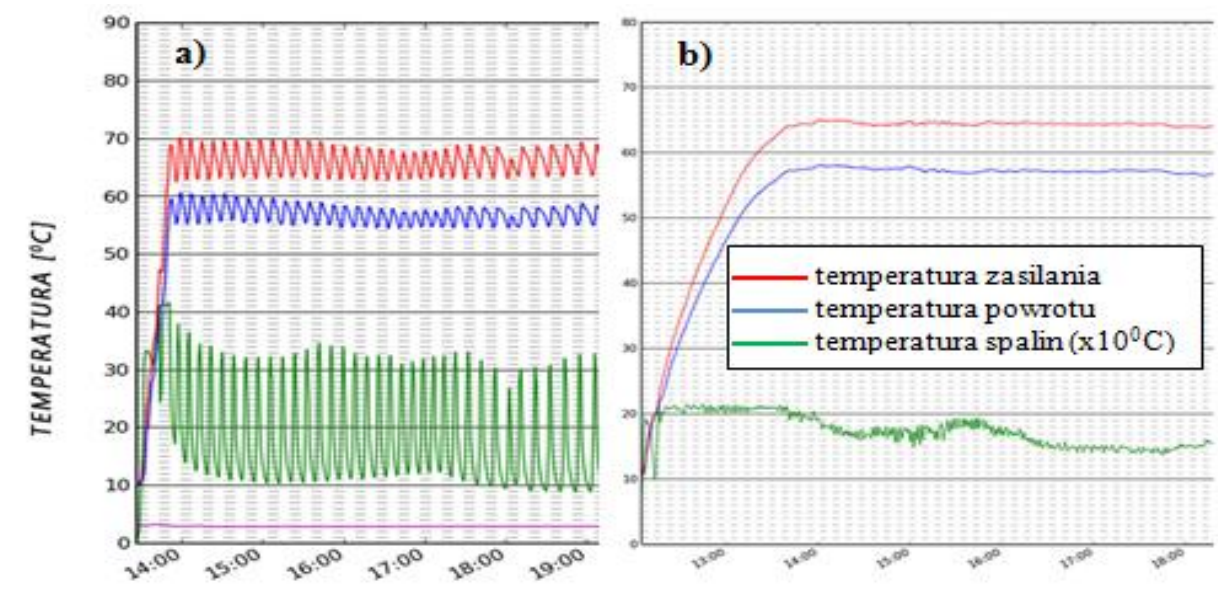

Rys. 1. Automatyczna regulacja wartości zadanej temperatury

a) bez wykorzystania regulatora PID, b) z wykorzystaniem regulatora PID

Czas jednego cyklu badań obiektu to trzy godziny, gdzie będą obserwowane dwie fazy pracy, tzn. rozpalanie płomienia wewnątrz paleniska i jego podtrzymanie. Badania zostały wykonane dla urządzenia o określonej mocy z zainstalowanym sterownikiem PID oraz bez - rys. 2a, b. Na rys. 2 c przedstawiono sumaryczną wartość poboru mocy przez w/w osprzęt obiektu technicznego. 
Wireless control process technical exploitation facility

Bezprzewodowe sterowanie procesem eksploatacji obiektu technicznego
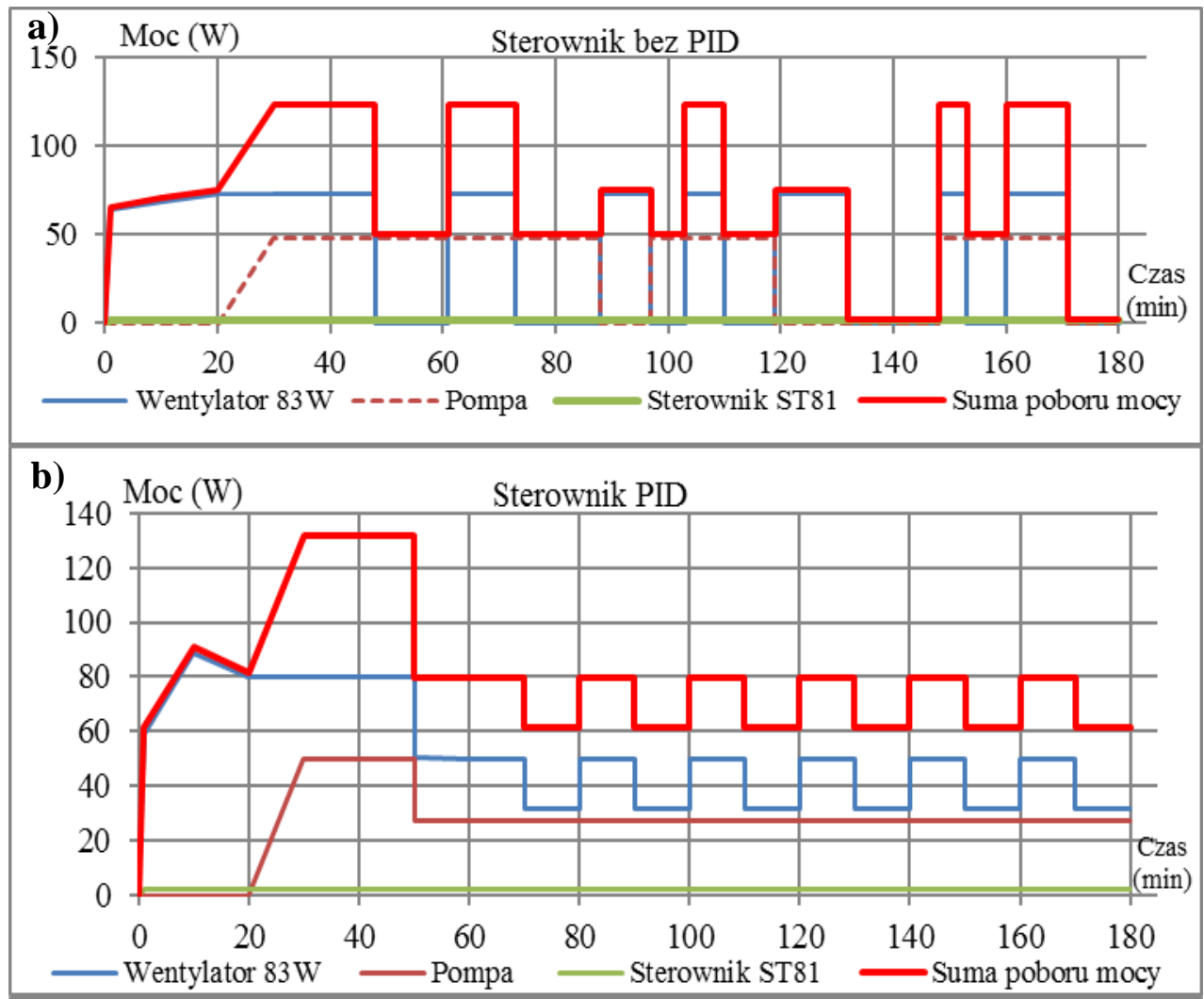

c) Porównanie poboru energi elektrycznej dla sterownika z i bez PID

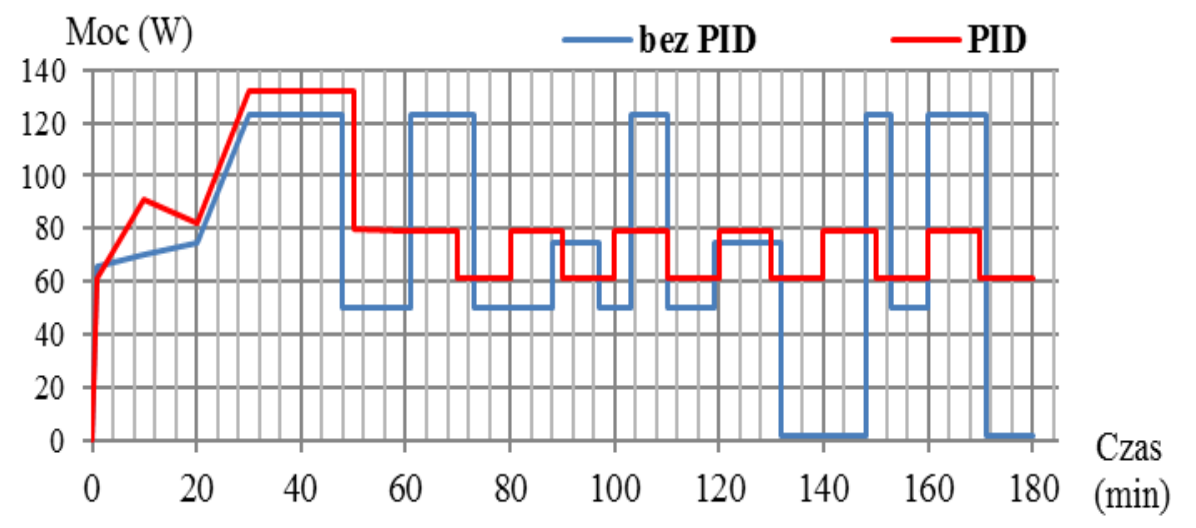

Rys. 2. Pobór mocy P[W] przez poszczególne urzadzenia podczas sterownia praca

a) bez sterownika PID, b) z wykorzystaniem sterownika PID, c) sumaryczne porównanie poboru mocy elektrycznej w urządzeniu z i bez sterownika 


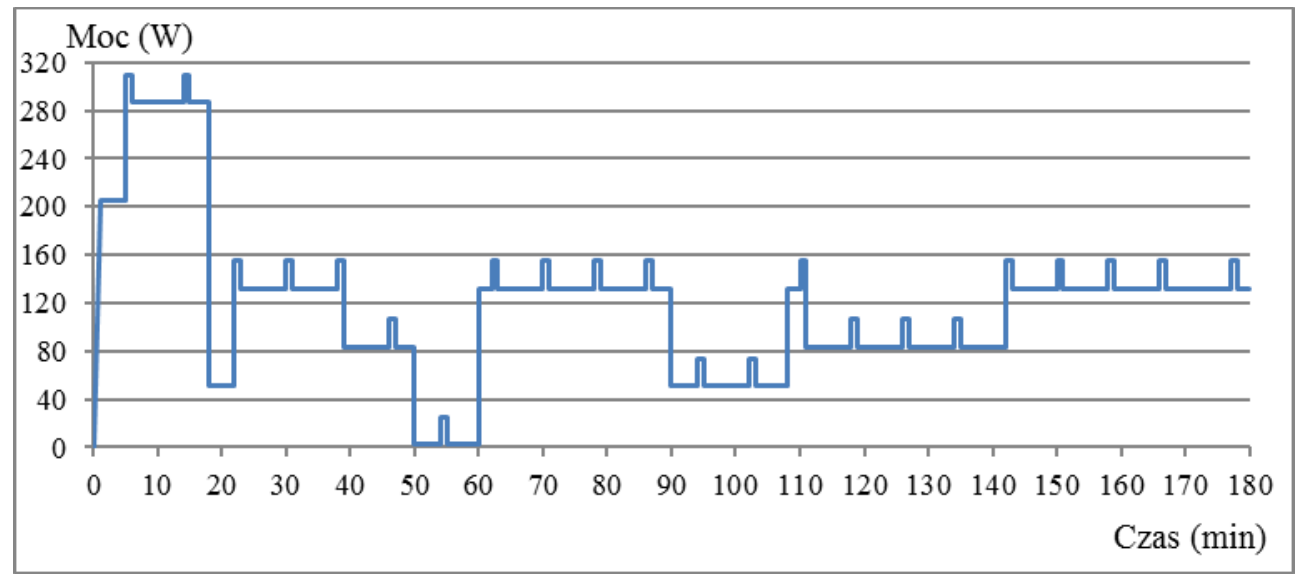

Rys.3. Wypadkowy pobór mocy elektrycznej dla kotta automatycznego

Cechą charakterystyczną procesu eksploatacji jest impulsowy pobór energii elektrycznej związanej z uruchomieniem silnika podajnika paliwa - rys. 3. Paliwo energetyczne podawane jest przez określony czas, później następuje ustalona przerwa która nie zależy od parametrów układu grzewczego.

\section{Model sterowania procesem eksploatacji obiektu}

Na rys. 4 przedstawiono model sterowania $\mathrm{z}$ użytkownikiem $\mathrm{w}$ pętli sprzężenia zwrotnego. Sterowanie kotłem odbywa się dzięki informacjom jakie można uzyskać samodzielnie bez udziału urządzeń elektronicznych wykorzystując jedynie wskazania czujników. W układzie sterowania - pojawiają się opóźnienia reakcji oddziaływania odczyt temperatury - człowiek - reakcja (pompy obiegowej lub wentylatora). Pomiar temperatury wody na wyjściu kotła oraz temperatury zewnętrznej z uwzględnieniem opóźnień, może doprowadzić do sytuacji niebezpiecznej dla użytkownika, tj. przekroczenia dopuszczalnej temperatury na wyjściu kotła. W efekcie prowadzi to do wybuchu, w przypadku gdy nie wystarczające są zabezpieczenia mechaniczne. Wraz z rozwojem technologii produkcji i sterowania wprowadzono urządzenia elektroniczne które umożliwiają dokładniejsze sterowanie - np. zmniejszenie czasów opóźnień. Dzięki temu wzrosły możliwości sterowania złożonym obiektem technicznym.

Zasada działania regulatora PID polega na tym, że regulator pracuje w pętli sprzężenia zwrotnego. Regulator oblicza wartość błędu regulacji jako różnicę pomiędzy zmierzoną wartością zmiennej procesu i pożądaną wartością zadaną. Reguluje wielkości w taki sposób, by zredukować uchyb. Regulator PID zawiera trzy podstawowe człony: proporcjonalny, całkujący i różniczkujący oznaczone odpowiednio P, I i D. Człon proporcjonalny regulatora PID powoduje wzmocnienie uchybu i zapewnia sukcesywne jego zmniejszanie. Wzrost wzmocnienia $\mathrm{K}_{\mathrm{p}}$ powoduje zmniejszanie zapasu stabilności, poszerzenie pasma roboczego i współczynnika astatyzmu. 
Wireless control process technical exploitation facility

Bezprzewodowe sterowanie procesem eksploatacji obiektu technicznego

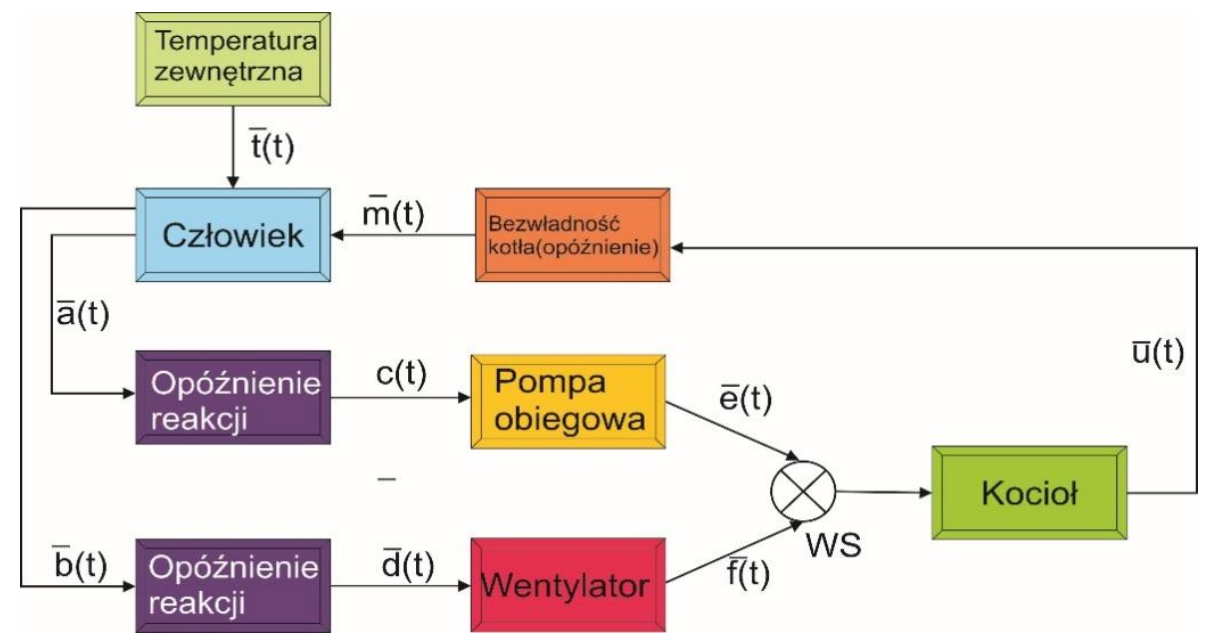

Rys. 4. Model sterowania eksploatacja - użytkownik w pętli sprzężenia zwrotnego

Przy skokowej zmianie sygnału regulującego występuje wartość skokowa. Jest ona proporcjonalna do zmiany sygnału wyjściowego, a występujący błąd regulacji nie jest całkowicie likwidowany (tzw. statyczny uchyb regulacji). Człon całkujący w regulatorze PID powoduje korekcję w zakresie małych częstotliwości, wprowadzając efekt astatyzmu. Człon całkujący dla większych częstotliwości zmniejsza znacznie wzmocnienie, ogranicza pasmo robocze jak również wprowadza przesunięcie fazy, równe $-\pi / 2$, prowadzące do pogorszenia stabilności. Człon całkujący reaguje wolniej na zmiany sygnału sterowanego. Wielkość regulowana oscylując wokół swojej wartości średniej sprowadza uchyb regulacji do zera. Połączone działanie wykorzystując zalety całkowania, eliminuje jego wady, gdyż nie wprowadza przesunięcia fazy i nie ogranicza pasma. Człon różniczkujący stosuje się $\mathrm{W}$ celu przyśpieszenia przebiegów zachodzących w układzie regulacji. Sygnał wyjściowy $\mathrm{z}$ członu różniczkującego jest proporcjonalny do prędkości zmian sygnału wejściowego, nie zależąc od jego amplitudy. W połączeniu z elementami całkującym i proporcjonalnym, działanie członu różniczkującego wprowadza do sygnału wyjściowego z regulatora składnik zależny od prędkości zmian uchybu regulacji. W sumie połączenie działań zapewnia zwiększenie zapasu stabilności, wzmocnienia i rozszerzenie pasma roboczego. W sterownikach z PID moc nadmuchu obliczana jest na podstawie pomiaru temperatury kotła i spalin. Praca wentylatora odbywa się w sposób ciągły w czasie, moc nadmuchu jest funkcją temperatury kotła, temperatury spalin i różnicy tych parametrów od wartości zadanych. Stabilne utrzymywanie temperatury bez zbędnych przeregulowań i oscylacji to zalety regulatora PID. Oszczędności w spalaniu paliwa z wykorzystaniem regulatora PID mogą wynosić od kilku do kilkunastu procent. 


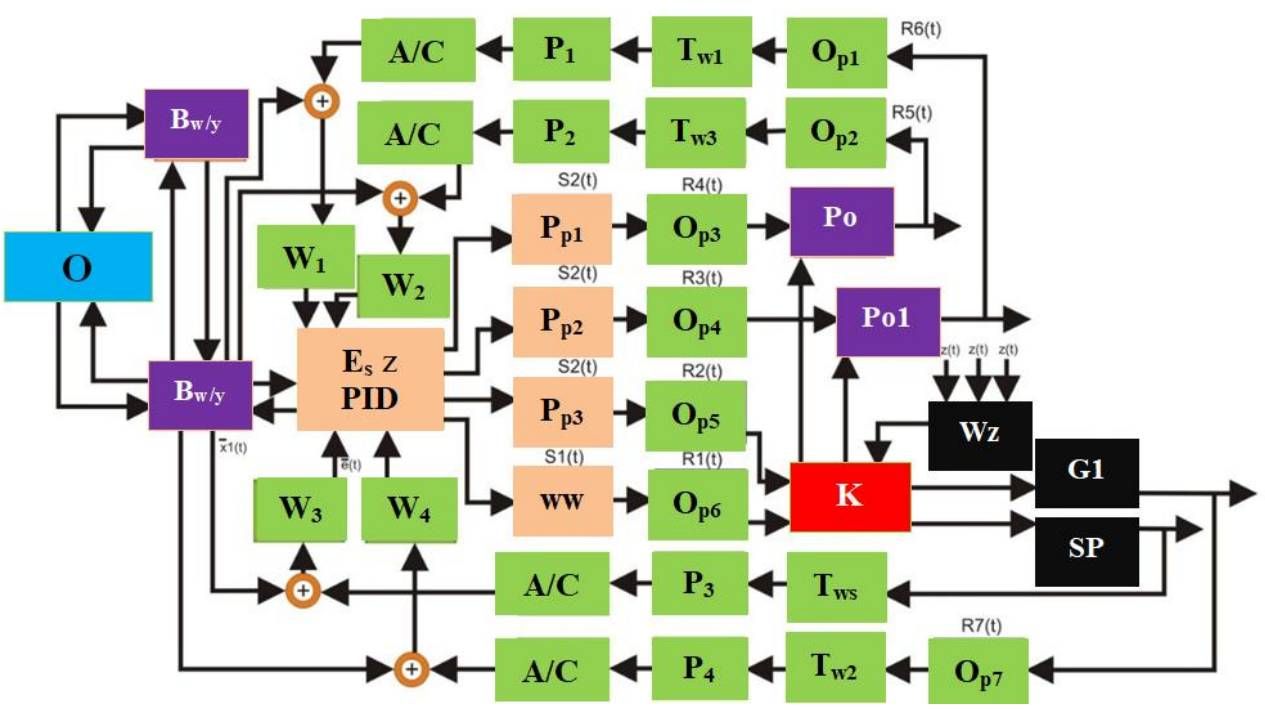

Rys. 5. Schemat modelu systemu z automatycznym podajnikiem paliwa gdzie: Op1 $\div$ Op 7 - opóźnienie związane z realizacja poszczególnych procesów sterowania kotta $\mathrm{CO}, \mathrm{A} / \mathrm{C}$ - przetwornik analogowo-cyfrowy, $\mathrm{W} 1 \div \mathrm{W} 4$

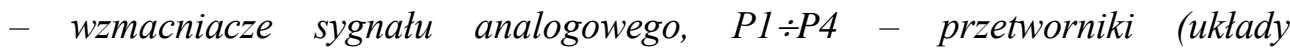
kondycjonowania sygnatu analogowego), Tw1 $\div$ Tw3 - czujnik temperatury wody, Tws - czujnik temperatury spalin, $K$ - kociol, $O$ - operator, Ppl $\div$ Pp 3 - pompy wody, ww-wentylator, Es - element sterujacy z regulatorem PID, Bw/y - blok przetwarzania sygnałów wejśsiowych $i$ wyjściowych sterowania, Po - proces ogrzewania, Pol - proces ogrzewania wody, Wz - warunki atmosferyczne zewnętrzne, G1 - proces ogrzewania wody w instalacji CO, SP - proces spalania $i$ dymienia.

\section{Badania eksperymentalne systemy sterowania obiektem}

W badaniach eksploatacyjnych systemu sterowania uwzględniono następujące parametry:

- czas opóźnienia komunikatu $\mathrm{t}_{\mathrm{op}}$ - różnica czasów nadania i odbioru komunikatu na wyjściu sterownika kotła $\mathrm{CO}$ - rys. 6;

- czasy reakcji obiektu na komunikat przekazany przez sterownik temperatury zainstalowany w pokoju a otrzymany za pomocą modułu GSM - rys. 7;

- określenie czasu rekcji sterownika na skok temperatury na wejściu kotła - rys. 8;

- wpływ operatora sieci na czas opóźnienia $t_{\text {op }}$ sterowaniem kotłem CO - rys. 9;

- wpływ usytuowania mobilnego terminalu na czas opóźnienia wysyłanego komunikatu - tab. 1;

- wpływ czasu wysłania komendy sterowania w dniu roboczym na $t_{\mathrm{op}}$ - rys. 10;

- średnie wartości czasów przesyłania poleceń sterowania wewnątrz obiektu sterowania (moduł sterowania - osprzęt elektryczny i elektroniczny) - rys. 11; 
Wireless control process technical exploitation facility

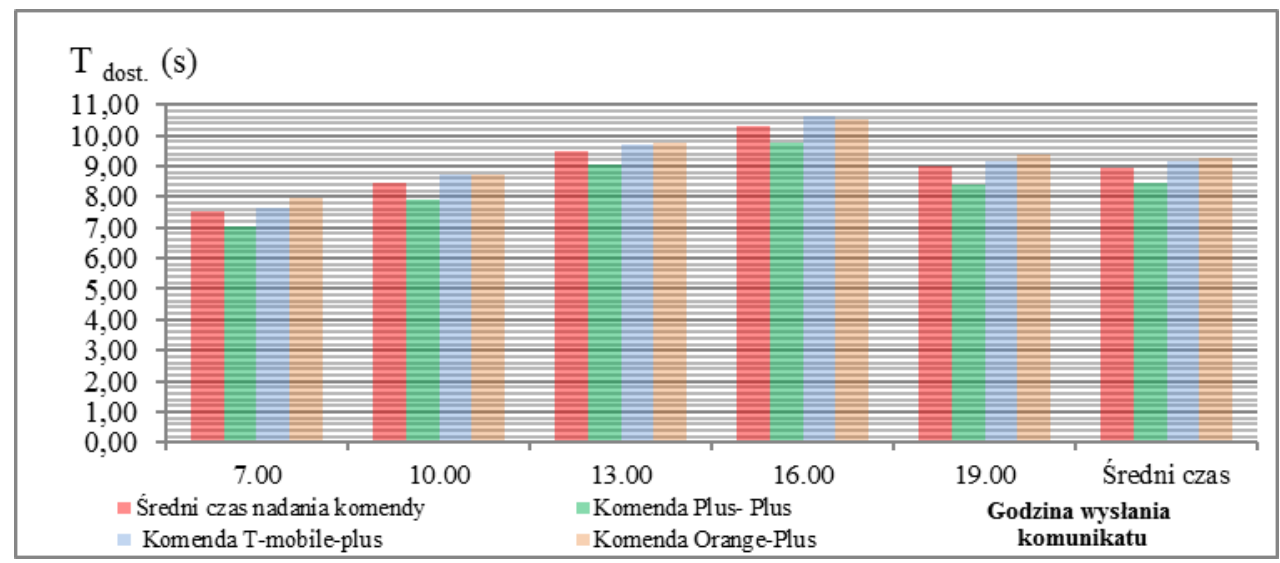

Rys. 6. Czas opóźnienia - wystanie komendy z terminala mobilnego a odbiór sygnatu sterujacego przez modut pieca $C O$ w ciagu dnia roboczego

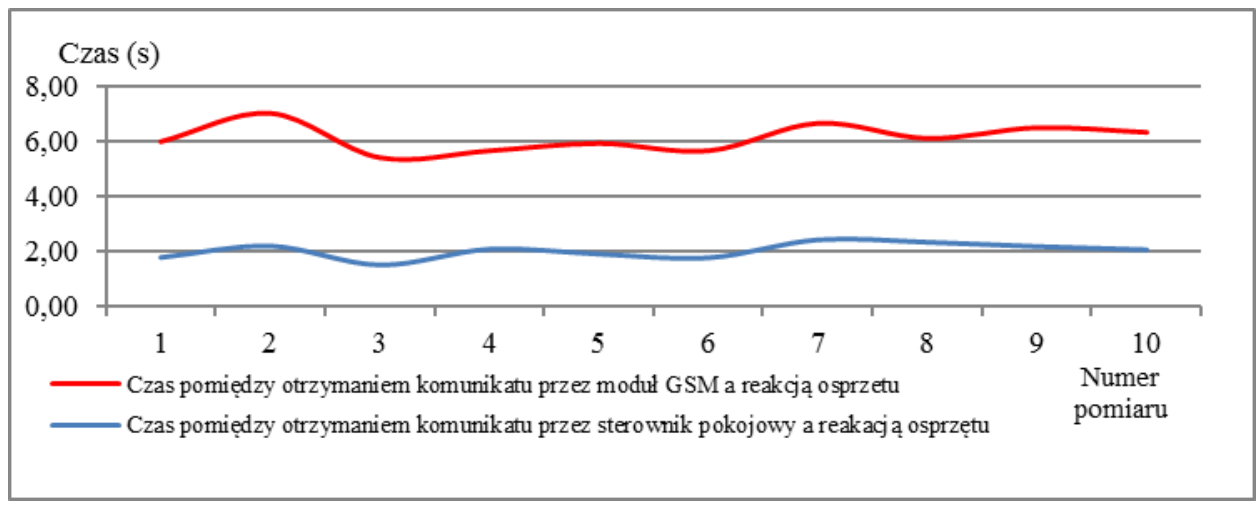

Rys. 7. Porównanie czasów reakcji otrzymania komunikatu przez sterownik temperatury zainstalowany $w$ pokoju z komunikatem otrzymanym za pomoca modutu GSM
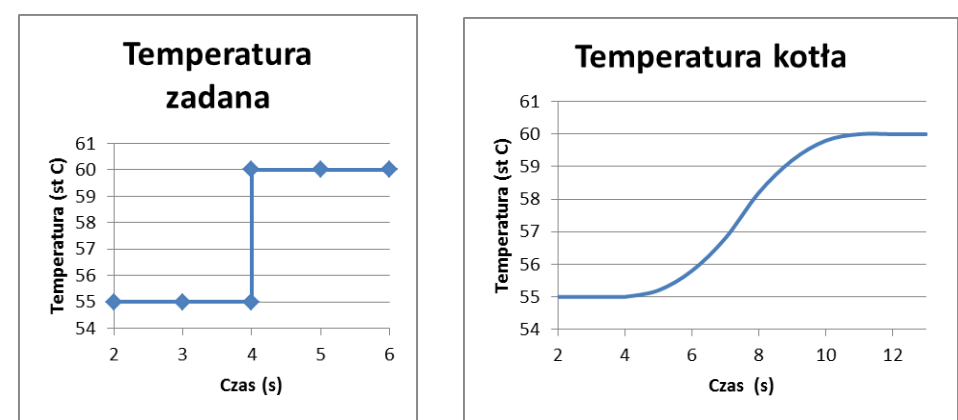

Rys. 8. Przebieg temperatury zadanej oraz odpowiedzi - temperatury wyjściowej $w$ systemie w przypadku wymuszenia skokowego na wejściu sterownika o $5^{0} \mathrm{C}$ 
Tabela 1. Uśrednione czasy komunikacji telefon mobilny a modut GSM sterownika obiektu technicznego

\begin{tabular}{|c|c|c|c|c|c|c|}
\hline \multicolumn{7}{|c|}{ Karta badań sterownika z modulem GSM - uśrednione } \\
\hline Data & 09.06 & \multicolumn{3}{|c|}{ Jednostka pomiarowa } & \multicolumn{2}{|c|}{ sekunda } \\
\hline Miejsce instalacji kotła & \multicolumn{6}{|c|}{$\mathrm{nn}$} \\
\hline Miejsce wysłania komendy & \multicolumn{6}{|c|}{ Uśrednione - $\mathrm{y}, \mathrm{z}, \mathrm{x}$} \\
\hline Godzina badania & 7.00 & 10.00 & 13.00 & 16.00 & 19.00 & \multirow{2}{*}{$\begin{array}{l}\text { Średni } \\
\text { czas }\end{array}$} \\
\hline & średnia & średnia & średnia & średnia & średnia & \\
\hline Średni czas nadania komendy & 7,55 & 8,44 & 9,50 & 10,32 & 8,97 & 8,96 \\
\hline Komenda Plus- Plus & 7,05 & 7,91 & 9,07 & 9,78 & 8,38 & 8,44 \\
\hline Komenda T-mobile-plus & 7,65 & 8,70 & 9,70 & 10,64 & 9,17 & 9,17 \\
\hline Komenda Orange-Plus & 7,94 & 8,72 & 9,75 & 10,54 & 9,37 & 9,26 \\
\hline $\begin{array}{l}\text { Średni czas doręczenie raportu od momentu } \\
\text { wyslania komendy }\end{array}$ & 14,51 & 16,44 & 18,64 & 20,11 & 17,48 & 17,44 \\
\hline Raport Plus- Plus & 13,82 & 16,02 & 18,22 & 19,47 & 16,77 & 16,86 \\
\hline Raport Plus-T-mobile & 14,45 & 16,36 & 18,76 & 20,37 & 17,69 & 17,52 \\
\hline Raport Plus - Orange & 15,27 & 16,94 & 18,93 & 20,50 & 17,98 & 17,92 \\
\hline $\begin{array}{l}\text { Średni Czas odpowiedzi sterownika od } \\
\text { momentu wyslania komendy }\end{array}$ & 20,27 & 22,05 & 24,06 & 25,74 & 23,14 & 23,05 \\
\hline Odpowiedz Plus- Plus & 19,57 & 21,48 & 23,63 & 25,28 & 22,42 & 22,48 \\
\hline Odpowiedz Plus-T-mobile & 20,75 & 22,58 & 24,60 & 26,34 & 23,69 & 23,59 \\
\hline Odpowiedz Plus-Orange & 20,50 & 22,09 & 23,95 & 25,60 & 23,30 & 23,09 \\
\hline
\end{tabular}

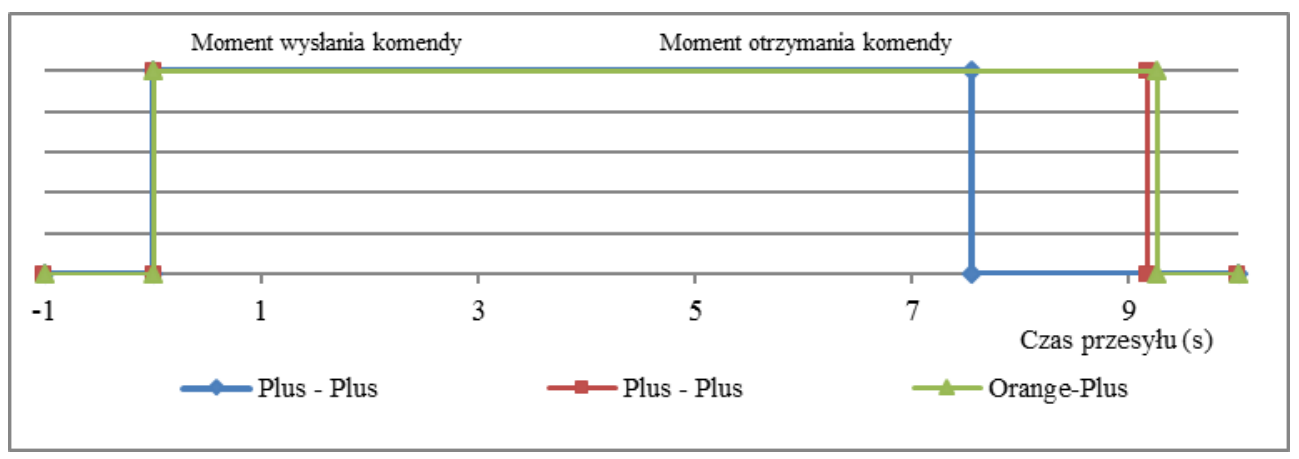

Rys. 9. Uśrednione czasy przesyłania komend w zależności od operatora sieci telefonii komórkowej 
Wireless control process technical exploitation facility

Bezprzewodowe sterowanie procesem eksploatacji obiektu technicznego

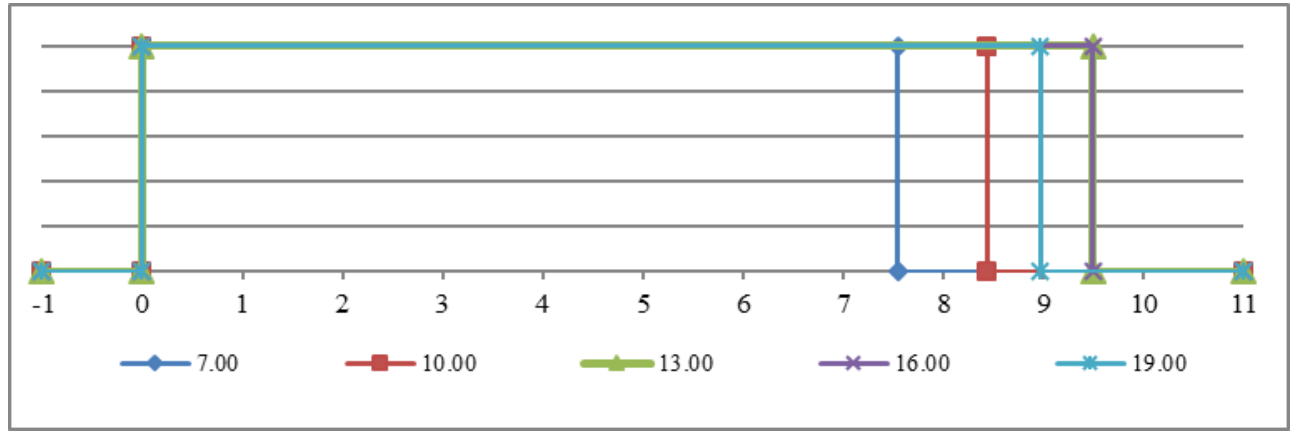

Rys. 10. Średnie wartości czasów przesyłania wiadomości sterujacej do obiektu w funkcji godziny wystania komunikatu (np. 13.00 - czas wystania komendy)

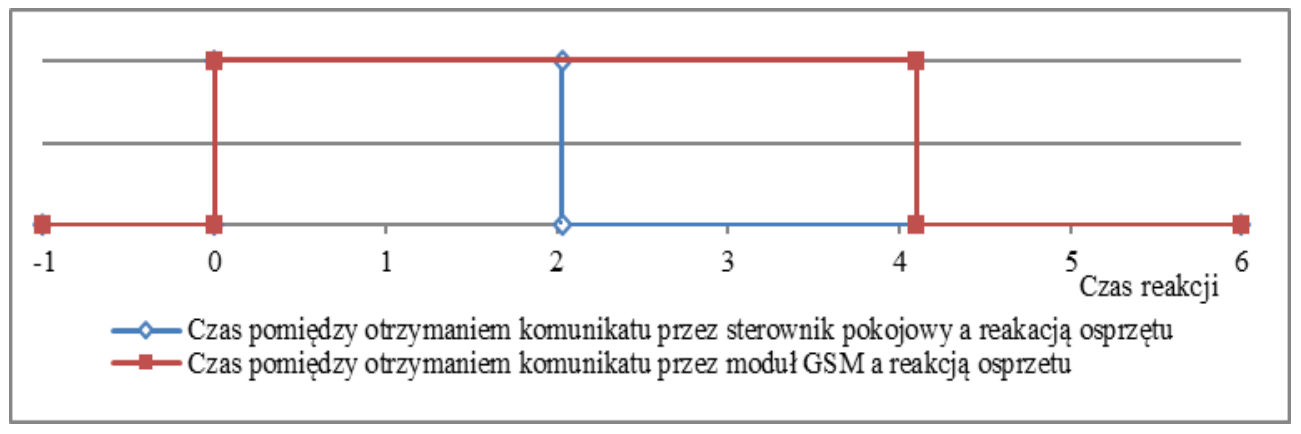

Rys. 11. Średnie wartości czasu przesyłania poleceń sterowania wewnątrz obiektu sterowania (modut sterowania $\rightarrow$ osprzęt elektryczny i elektroniczny obiektu)

\section{Wnioski}

W opracowaniu przedstawiono wyniki badań możliwości wykorzystania sterownia bezprzewodowego dla obiektu technicznego $\mathrm{z}$ wykorzystaniem mobilnego terminala telefonicznego. Rozwiązania techniczne oraz zastosowany osprzęt elektryczny i elektroniczny obiekt umożliwiają stosowanie tego typu rozwiązań. W wyniku przeprowadzonych badań technicznych czasów opóźnienia nadawanych i odebranych komunikatów w systemie eksploatacji można stwierdzić wpływ następujących parametrów na jakość sterowania: miejsce instalacji obiektu (pomieszczenie, ukształtowanie terenu, zabudowa, odległość od stacji nadawczoodbiorczej); godzina nawiązywania łączności (w godzinach porannych czas przesyłania wiadomości jest znacznie krótszy 7,5 $\mathrm{s}$ niż $\mathrm{w}$ godzinach popołudniowych 9,5 s); czasy przesyłania komend sterowania zależą od operatora sieci telefonii komórkowej (sieć Plus - 7,4 s, Orange 9,3 s); rodzaju komunikacji /sterowania wewnętrzne lub zewnętrzne (czas reakcji na zmiany temperatury uzależniony od rodzaju wykorzystanego sterownika - pokojowy lub moduł GSM). 


\section{Literatura}

[1] Będkowski L., Dąbrowski T.: Podstawy eksploatacji, cz. II Podstawy niezawodności eksploatacyjnej. Warszawa: Wojskowa Akademia Techniczna, 2006.

[2] Staniszewski R.: Sterowanie procesem eksploatacji, WNT Warszawa 1990.

[3] Węgrzyn S.: Podstawy automatyki, PWN, Warszawa 1980.

[4] Dyduch J., Paś J., Rosiński A.: Podstawy eksploatacji transportowych systemów elektronicznych. Wydawnictwo Politechniki Radomskiej, Radom 2011.

[5] Laskowski, D., Łubkowski, P., Pawlak, E., Stańczyk, P.: Anthropotechnical systems reliability. In: the monograph „Safety and Reliability: Methodology and Applications - Proceedings of the European Safety and Reliability Conference ESREL 2014", editors: Nowakowski T., Młyńczak M., JodejkoPietruczuk A. \&Werbińska-Wojciechowska S. CRC Press/Balkema, London, 2015, pp. 399-407.

[6] Paś J.: Eksploatacja elektronicznych systemów transportowych. Uniwersytet Technologiczno - Humanistyczny, Radom 2015.

[7] Rosiński A.: Modelowanie procesu eksploatacji systemów telematyki transportu. Oficyna Wydawnicza Politechniki Warszawskiej, Warszawa 2015.

[8] Rosiński A.: Reliability-exploitation analysis of power supply in transport telematics system. In: „Safety and Reliability: Methodology and Applications - Proceedings of the European Safety and Reliability Conference ESREL2

[9] Siergiejczyk M., Rosiński A., Paś J.: Analysis of unintended electromagnetic fields generated by safety system control panels. Diagnostyka 2016, vol. 17, no. 3, pp. 35-40.

[10] Paś J.: Shielding of the electromagnetic field in the range of small frequencies as the factor for ensuring compatibility in electronic transportation systems. Archives of Transport System Telematics, pp. 36 - 41, Volume 9, Issue 3, September 2016

[11] Paś J., Choromański W.: Results of measurement and determination of threshold electric field component for transport security systems. Archives of Transport Systems Telematics, pp. 24 - 29, Volume 8, Issue 1, February 2015

[12] T. Perzyński, A. Lewiński, Z. Lukasik, "Safety analysis of accidents call system especially related to in-land water transport based on new telematic solutions," in Communications in Computer and Information Science, Tools of Transport Telematics, no. 531, Berlin Heidelberg, Germany: SpringerVerlag, 2015, pp. 90-98.

[13] M. Stawowy, "Model for information quality determination of teleinformation systems of transport," in Proceedings of the European Safety and Reliability Conference ESREL 2014, Wroclaw, Poland, 2015, pp.1909-1914.

[14] M. Sumila, "Selected aspects of message transmission management in ITS systems," in Telematics in the transport environment, vol. 329, Berlin Heidelberg, Germany: Springer-Verlag, 2012, pp. 141-147. 
Wireless control process technical exploitation facility

Bezprzewodowe sterowanie procesem eksploatacji obiektu technicznego

[15] P. Łubkowski, D. Laskowski, "Selected issues of reliable identification of object in transport systems using video monitoring services," in Communication in Computer and Information Science, vol. 471, Berlin Heidelberg, Germany: Springer, 2015, pp. 59-68.

[16] S. Duer, K. Zajkowski, R. Duer, J. Paś, "Designing of an effective structure of system for the maintenance of a technical object with the using information from an artificial neural network," Neural Computing \& Applications, vol. 23, issue 3, pp. 913-925, 2012

[17] M. Siergiejczyk, J. Paś, A. Rosiński, "Issue of reliability-exploitation evaluation of electronic transport systems used in the railway environment with consideration of electromagnetic interference," IET Intelligent Transport Systems, vol. 10, issue 9, pp. 587-593, 2016. DOI: 10.1049/iet-its.2015.0183.

[18] M. Siergiejczyk, J. Paś, A. Rosiński, "Modeling of process of exploitation of transport telematics systems with regard to electromagnetic interferences," in Tools of transport telematics", vol. 531, Berlin Heidelberg, Germany: Springer, 2015. pp. 99-107.

[19] S. Dudoyer, V. Deniau, S. Ambellouis, M.Heddebaut, A. Mariscotti, "Classification of transient EM noises depending on their effect on the quality of GSM-R reception," IEEE Transactions on Electromagnetic Compatibility, vol. 55, no. 5, pp. 867-874, 2013. 32

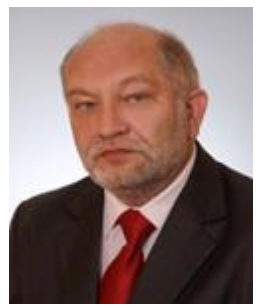

Dr hab. inż. Jacek Paś, profesor nadzwyczajny na Wydziale Elektroniki Wojskowej Akademii Technicznej. Jego zainteresowania naukowe obejmuja analize niezawodnościowoeksploatacyjna elektronicznych systemów bezpieczeństwa, systemów telematyki transportu oraz zagadnienia kompatybilności elektromagnetycznej. $W$ dorobku naukowym posiada kilkadziesiąt publikacji naukowych. 